\title{
Przerwa w terapii empagliflozyną u pacjenta z niewydolnością serca z obniżoną frakcją wyrzutową i hospitalizacja z powodu zaostrzenia niewydolności serca
}

\author{
A break in pharmacotherapy with empagliflozin in a patient \\ with heart failure with reduced ejection fraction and hospitalization caused \\ by exacerbation of heart failure
}

\author{
Agnieszka Komorowska, Małgorzata Lelonek iD \\ Zakład Kardiologii Nieinwazyjnej Katedry Chorób Wewnętrznych i Kardiologii Uniwersytetu Medycznego w Łodzi
}

\section{Streszczenie}

Mężczyznę w wieku 56 lat z ciężką dysfunkcją lewej komory przyjęto na oddział z powodu zaostrzenia objawów przewlekłej niewydolności serca z obniżoną frakcją wyrzutową lewej komory. W trakcje hospitalizacji stosowano standardowe leczenie niewydolności serca, ale także modyfikowano terapię chorób współistniejących, w tym cukrzycy. Na podstawie opisu przypadku klinicznego w artykule przedstawiono aktualny stan wiedzy na temat korzystnego wpływu empagliflozyny na układ sercowo-naczyniowy.

Słowa kluczowe: niewydolność krążenia z obniżona frakcją wyrzutowa lewej komory, empagliflozyna

Folia Cardiologica 2019; 14, 2: 199-205

\section{Wstęp}

Według wytycznych Europejskiego Towarzystwa Kardiologicznego (ESC, European Society of Cardiology) z 2016 roku [1] niewydolność serca (HF, heart failure) to zespół typowych objawów podmiotowych (tj. duszność, obrzęki kończyn dolnych, obniżenie tolerancji wysiłku), którym mogą towarzyszyć odchylenia w badaniu przedmiotowym (takie jak poszerzenie żył szyjnych, trzeszczenia nad płucami, obrzęki obwodowe), spowodowane zaburzeniami w budowie i/lub czynności serca powodujące zmniejszony rzut serca i/lub zwiększone ciśnienia wewnątrzsercowe w spoczynku lub w trakcie wysiłku. Do oceny nasilenia ciężkości objawów stosuje się klasyfikację według New York Heart Association (NYHA), która - choć słabo koreluje z większością parametrów opisujących funkcję lewej komory - pozostaje istotnym parametrem w ocenie chorego z HF [1]. Wiadomo, że nasilenie objawów w klasyfikacji według NYHA wiąże się ze zwiększonym ryzykiem hospitalizacji, a także zgonu [2, 3].

Ponadto choroby wspótistniejące mogą nasilać objawy HF, zwiększając tym samym ryzyko hospitalizacji oraz zgonu w przebiegu zaostrzenia HF. Według wytycznych ESC obecność cukrzycy wiąże się z gorszym stanem czynnościowym i gorszym rokowaniem. W badaniu Framingham [4] udowodniono, że ryzyko wystapienia HF u chorego na cukrzyce jest prawie 2,4-krotnie wyższe u mężczyzn oraz 5-krotnie wyższe u kobiet niż u osób niechorujących na cukrzycę. Wykazano także, że wzrost stężenia hemoglobiny glikowanej $\left(\mathrm{HbA}_{1}\right.$, glycated haemoglobin) o 1\% powoduje wzrost ryzyka HF o 8\% niezależnie od wieku, obecności choroby wieńcowej, wartości ciśnienia tętniczego czy stopnia otyłości [5].

Co więcej, relacja między HF a cukrzycą jest niczym miecz obosieczny, ponieważ pacjentów chorujących na cukrzyce cechuje większe prawdopodobieństwo rozwoju

Adres do korespondencji: prof. dr hab. n. med. Małgorzata Lelonek FESC, Zakład Kardiologii Nieinwazyjnej, Katedra Chorób Wewnętrznych i Kardiologii, Uniwersytet Medyczny w Łodzi, ul. Żeromskiego 113, 90-549 Łódź, e-mail: malgorzata.lelonek@umed.lodz.pl 
HF w związku z procesami toczącymi się w obrębie układu sercowo-naczyniowego. Hiperinsulinemia, hiperglikemia, kwasica oraz insulinooporność to czynniki, które poprzez modyfikację szlaków komórkowych w kardiomiocycie prowadzą do remodelingu serca. Obecnie można wyróżnić dwa dominujące procesy toczące się w sercu chorego na cukrzycę. Pierwszy prowadzi do dysfunkcji lewej komory (LV, left ventricle) i wynika głównie z intoksykacji kardiomiocytów poprzez substraty nieprawidłowych procesów metabolicznych w komórce (w tym składowanie wolnych kwasów tłuszczowych, a w konsekwencji stłuszczenie komórek serca; zmiany w mechanizmach regulacji równowagi elektrolitowej wewnątrz- i zewnątrzkomórkowej, a co za tym idzie - właściwości elektrofizjologicznej miokardiocytu). Nie bez znaczenia pozostają także modyfikacje w zakresie szlaków przemian metabolicznych, stres oksydacyjny, dysfunkcja mitochondriów czy uszkodzenie śródbłonka naczyń, co prowadzi do obumarcia komórek mięśnia sercowego. Drugi wynika z przewlekłej reakcji zapalnej i zwiększonej w konsekwencji syntezy kolagenu i nasilonego włóknienia [6].

Wśród chorych na cukrzycę częściej rejestrowano dysfunkcje skurczową i rozkurczową oraz arytmię. Polineuropatia cukrzycowa i przewaga aktywności układu współczulnego nad aktywnością układu przywspółczulnego wraz ze zmianami w budowie histopatologicznej serca (proces włóknienia) oraz obniżeniem frakcji wyrzutowej LV predysponują u tych chorych do rozwoju arytmii, w tym zagrażającej życiu arytmii komorowej.

\section{Opis przypadku}

Mężczyzna w wieku 56 lat został przyjęty do szpitala z powodu pogorszenia tolerancji wysiłku do III klasy według NYHA, duszności oraz narastania obrzęków kończyn dolnych do wysokości kolan z ciśnieniem tętniczym 135/85 mm Hg (chory ciepły, mokry wg klasyfikacji Forrestera).

W wywiadzie stwierdzono:

- ciężką dysfunkcję skurczową LV;

- stan po implantacji kardiowertera-defibrylatora z funkcją resynchronizacji (CRT-D, cardiac resynchronization therapy with defibrillator);

- umiarkowaną stenozę aortalną;

- przewlekłą chorobę wieńcową - stan po zawale serca z uniesieniem odcinka ST ściany dolnej i prawej komory leczony dwukrotną nieskuteczną próbą rewaskularyzacji prawej tętnicy wieńcowej powikłaną przemijającym blokiem przedsionkowo-komorowym III stopnia; stan po zawale serca bez uniesienia odcinka ST leczonym angioplastyką gałęzi okalającej z implantacją dwóch stentów uwalniających lek (DES, drug-eluting stent);

- nadciśnienie tętnicze (maks. ciśnienie tętnicze 170/ /90 mm Hg);

- cukrzyce typu 2 w trakcie terapii metforminą;

- hiperlipidemię mieszaną w trakcie terapii statyną;
- otyłość (wskaźnik masy ciała [BMI, body mass index] $40,56 \mathrm{~kg} / \mathrm{m}^{2}$, wzrost $172 \mathrm{~cm}$, masa ciała $120 \mathrm{~kg}$ ), zespół metaboliczny;

- napadowe migotanie przedsionków.

W badaniach laboratoryjnych spośród istotnych odchyleń od normy stwierdzono obniżone parametry nerkowe oraz podwyższone stężenia glukozy i triglicerydów oraz N-końcowego propeptydu natriuretycznego typu B (NT-proBNP, $\mathrm{N}$-terminal pro-B-type natriuretic peptide), aczkolwiek - ze względu na otyłość - wynik był niewspółmiernie niski do objawów występujących u chorego (tab. 1 - pobyt 1.).

W elektrokardiogramie (EKG) przy przyjęciu rejestrowano miarowy zatokowy rytm serca (HR, heart rate) około 90/ /min ze skuteczną stymulacją resynchronizującą o typie AS-BiVP (atrial synchronous biventricular pacing). Wyczuwanie i stymulacja były prawidłowe.

W trakcie hospitalizacji wykonano badanie echokardiograficzne serca, potwierdzając ciężką dysfunkcję skurczową lewej komory (LVEF [left ventricular ejection fraction] 24\%, wymiar końcoworozkurczowy lewej komory [LVEDd, left ventricular end-diastolic diameter] $65 \mathrm{~mm}$, stosunek objętości końcoworozkurczowej do objętości końcowoskurczowej lewej komory [EDV/ ESV, end-diastolic volume/end-systolic volume] 250/190 ml) z odcinkowymi zaburzeniami kurczliwości ścian dolnej i tylnej oraz z umiarkowanym zwężeniem zastawki tętnicy głównej i upośledzoną funkcją skurczową powiększonej prawej komory (amplituda ruchu pierścienia zastawki trójdzielnej [TAPSE, tricuspid annular plane systolic excursion] 16 mm, S' $9 \mathrm{~cm} / \mathrm{s}$, wymiar proksymalny prawej komory [RVD prox, right ventricular diameter proximal] $35 \mathrm{~mm}$ ).

W trakcie hospitalizacji chorego poddano intensywnemu moczopędnemu leczeniu dożylnemu oraz utrzymano standardowe leczenie HF (inhibitorami konwertazy angiotensyny [ACE, angiotensin-converting enzyme], beta-adrenolitykami, antagonistami receptora mineralokortykoidowego [MRA, mineralocorticoid receptor antagonists]). Po uzyskaniu poprawy stanu ogólnego oraz zmniejszeniu objawów HF przeprowadzono 6-minutowy test marszu (6-MWT, 6-minute walk test), w którym chory osiągnął $290 \mathrm{~m}$.

W wykonanej kontrolnej koronarografii uwidoczniono dobry efekt implantacji stentów do gałęzi okalającej oraz amputację prawej tętnicy wieńcowej z wytworzonym krążeniem obocznym. Chorego zakwalifikowano do dalszego leczenia zachowawczego.

W MAGGIC (Meta-Analysis Global Group in Chronic Heart Failure) score rokowanie oceniono na poważne (26 pkt., śmiertelność roczna 17,5\%, śmiertelność 3-letnia 39,7\%.) W okresie przedwypisowym zmodyfikowano terapię cukrzycy, dołączając do metforminy empagliflozynę.

Chorego wypisano z zaleceniem dalszego leczenia ambulatoryjnego na następującym leczeniu: dabigatran 2 razy $110 \mathrm{mg}$, atorwastatyna $20 \mathrm{mg}$, bisoprolol 7,5 mg, amiodaron $200 \mathrm{mg}$, ramipril $5 \mathrm{mg}$, lerkanidipina $10 \mathrm{mg}$, 
Tabela 1. Wyniki podstawowych badań laboratoryjnych podczas kolejnych hospitalizacji

\begin{tabular}{|c|c|c|c|c|}
\hline \multirow[t]{2}{*}{ Parametr } & \multicolumn{3}{|c|}{ Wynik } & \multirow[t]{2}{*}{ Norma } \\
\hline & Pobyt 1. & Pobyt 2. & Pobyt 3. & \\
\hline $\operatorname{WBC}\left[\times 10^{3} / \mu \mathrm{l}\right]$ & 7,30 & 10,57 & 6,84 & $4,00-11,00$ \\
\hline $\mathrm{RBC}\left[\times 10^{6} / \mu \mathrm{l}\right]$ & 5,32 & 4,38 & 4,84 & $4,20-6,10$ \\
\hline $\mathrm{Hb}[\mathrm{g} / \mathrm{dl}]$ & 15,9 & 14,2 & 15,1 & $14,0-18,0$ \\
\hline $\mathrm{TC}[\mathrm{mmol} / \mathrm{l}]$ & 3,83 & Brak danych & 5,07 & $3,00-5,00$ \\
\hline LDL [mmol/l] & 1,25 & Brak danych & 2,59 & $<1,8$ \\
\hline $\mathrm{HDL}[\mathrm{mmol} / \mathrm{I}]$ & 0,95 & Brak danych & 1,24 & $>1,00$ \\
\hline $\mathrm{TG}[\mathrm{mmol} / \mathrm{l}]$ & 3,58 & Brak danych & 2,73 & $<1,70$ \\
\hline Glukoza & 8,55 & 8,28 & 7,97 & $4,1-5,5$ \\
\hline Kreatynina $[\mu \mathrm{mol} / \mathrm{l}]$ & 148 & 150 & 131,7 & $59-104,0$ \\
\hline eGFR [ml/min/1,73 m²] & 46,5 & 54,44 & 67 & $>60$ \\
\hline $\mathrm{Na}[\mathrm{mmol} / \mathrm{l}]$ & 136 & 141 & 140,1 & $136-146$ \\
\hline $\mathrm{K}$ [mmol/l $]$ & 4,38 & 4,3 & 4,26 & $3,5-5,1$ \\
\hline AspAT [j./l] & 34 & Brak danych & 36,7 & $0,0-35$ \\
\hline AIAT [j./I] & 35 & 30 & 28,8 & $0,0-45$ \\
\hline $\mathrm{CRP}[\mathrm{mg} / \mathrm{l}]$ & 2,9 & 8,48 & 2,8 & $0,0-6,0$ \\
\hline 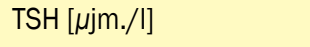 & 0,672 & Brak danych & 0,588 & $0,27-4,20$ \\
\hline NT-proBNP [pg/ml] & 488 & Brak danych & 324,7 & $<125$ \\
\hline $\mathrm{TnT}[\mathrm{ng} / \mathrm{ml}]$ & Brak danych & Brak danych & 39 & $<14$ \\
\hline
\end{tabular}

WBC (white blood count) - liczba krwinek białych; RBC (red blood count) - liczba krwinek czerwonych; Hb (haemoglobin) - hemoglobina; TC (total cholesterol) - cholesterol całkowity; LDL (low-density lipoproteins) - lipoproteiny o niskiej gęstości; HDL (high-density lipoproteins) - lipoproteiny o wysokiej gesstości; TG (triglycerides) - triglicerydy; eGFR (estimated glomerular filtration rate) - szacowany współczynnik filtracji kłębuszkowej; $\mathrm{Na}$ - wapń; $\mathrm{K}$ - potas; AspAT (aspartate aminotransferase) - aminotransferaza asparaginianowa; AlAT (alanine aminotransferase) - aminotransferaza alaninowa; CRP (C-reactive protein) - białko C-reaktywne; TSH (thyroid-stimulating hormone) - hormon tarczycy; NT-proBNP (NT-proBNP, N-terminal pro-B-type natriuretic peptide) - N-końcowy propeptyd natriuretyczny typu B; TnT (troponin T) - troponina T

eplerenon $50 \mathrm{mg}$, pantoprazol $20 \mathrm{mg}$, empagliflozyna $10 \mathrm{mg}$, torasemid $10 \mathrm{mg}$, metformina 3 razy $850 \mathrm{mg}$.

W trakcie kontrolnej wizyty w poradni kardiologicznej po około 2 miesiącach od hospitalizacji obserwowano stabilny stan kliniczny i zadowalającą tolerancja wysiłku II klasy według NYHA; stężenie NT-proBNP wyniosło 153 pg/dl. W kontroli CRT rejestrowano istotne zmniejszenie impedancji korespondujące z poprawą kliniczną. Jednak po 4 miesiącach chory był hospitalizowany z powodu kolejnego zaostrzenia HF, ze stężeniem NT-proBNP 1586 pg/ml, i podczas tej hospitalizacji został włączony do programu terapii lekiem sakubitril/walsartan w dawce 97/103 mg. Przez ponad rok pozostawał stabilny klinicznie, nie wymagając hospitalizacji z powodu nasilenia HF.

Kolejna hospitalizacja wiązała się z infekcją dróg oddechowych, w przebiegu której doszło do zaostrzenia HF. Chorego hospitalizowano na rejonowym oddziale chorób wewnętrznych z powodu duszności o typie ortopnoë, kaszlu z odkrztuszaniem żółto-szarej wydzieliny w przebiegu infekcji dróg oddechowych i narastania obrzęków kończyn dolnych. W badaniu ogólnym moczu przy przyjęciu wykryto obecność glukozy, a glikemia z krwi żylnej wynosiła $149 \mathrm{mg} / \mathrm{dl}$ (tab. 1 - pobyt 2.), było to zatem efektem leczenia empagliflozyną. Po zastosowaniu antybiotykoterapii oraz dożylnego leczenia moczopędnego chorego wypisano do domu z poprawą kliniczną. Nie kontynuowano terapii empagliflozyną.

Po kontrolnej wizycie (ok. 3 miesiące od ostatniej hospitalizacji) w poradni kardiologicznej, ze względu na znaczne zwiększenie masy ciała (ok. $10 \mathrm{~kg}$ ), nasilenie obrzęków kończyn dolnych do kolan oraz nasilenie HF do III/IV klasy według NYHA chorego skierowano do szpitala z rozpoznaniem zaostrzenia HF (wyniki badań laboratoryjnych w tab. 1 - pobyt 3.). Zastosowano pełne leczenie niewydolności krążenia, w tym dożylne leki moczopędne i wlew z lewosimendanu, uzyskując znaczną poprawę stanu ogólnego, zmniejszenie masy ciała i ograniczenie obrzęków oraz duszności. W okresie okołowypisowym, zważywszy na HR powyżej 75/min w spoczynku, do beta-adrenolityku dołączono iwabradynę. Wynik $\mathrm{HbA}_{1 \mathrm{c}}$ miał wartość 9,10\%, co świadczyło o niezadawalających glikemiach w ostatnich 3 miesiącach rzędu 11,8 mmol/l (tj. $212 \mathrm{mg} / \mathrm{dl}$ ).

U opisywanego pacjenta dotychczasowe postępowanie niefarmakologiczne okazało się, niestety, nieskuteczne. Należy podkreślić, że z jednej strony otyłość olbrzymia (BMI 40,56 g/ $\mathrm{m}^{2}$ ) łączy się z hiperinsulinemią, co prowadzi do aktywacji układu renina-angiotensyna-aldosteron (RAA) i, wtórnie, nasilenia HF. Z drugiej strony stosowanie 
u tego typu chorego insuliny, która powoduje retencję sodu i przy jednoczesnym zmniejszaniu glikozurii może nasilać retencję płynów, nie byłoby optymalnym rozwiązaniem. Dlatego po osiągnięciu stabilności klinicznej w okresie okołowypisowym powrócono do leczenia empagliflozyną. W 6-MWT chory osiągnął dystans marszu $330 \mathrm{~m}$. Poddano go edukacji dotyczącej HF i cukrzycy.

Chorego wypisano do domu z zaleceniami niefarmakologicznymi oraz z następującymi zaleceniami dotyczącymi farmakoterapii: dabigatran 2 razy $110 \mathrm{mg}$, sakubitril/walsartan 2 razy 97/103 mg, iwabradyna 2 razy $5 \mathrm{mg}$, atorwastatyna $80 \mathrm{mg}$, bisoprolol $10 \mathrm{mg}$, amiodaron $200 \mathrm{mg}$, lerkanidipina 10, eplerenon $25 \mathrm{mg}$, pantoprazol $20 \mathrm{mg}$, empagliflozyna $10 \mathrm{mg}$, furosemid $40 \mathrm{mg}$, torasemid $20 \mathrm{mg}$, metformina 3 razy $1000 \mathrm{mg}$. W trakcie kolejnej wizyty kontrolnej po miesiącu stosowania przez chorego powyższego leczenia obserwowano stabilny obraz kliniczny, ciśnienie tętnicze 125/70 mm Hg i glikemię do 150 mg/dl na czczo oraz zmniejszenie masy ciała o $5 \mathrm{~kg}$. W ocenie echokardiograficznej zarejestrowano nieznaczną poprawę LVEF (28\%) i zmniejszenie wymiarów LVEDd (61 mm). W ergospirometrii chory przy obciążeniu $100 \mathrm{~W}$ osiągnął objętość tlenu zużywanego przez organizm $\left(\mathrm{VO}_{2}\right)$ 12,74 ml/ /kg mc./min, współczynnik wymiany oddechowej (RER, respiratory exchange ratio) $1,16, \mathrm{VO}_{2}$ na tak zwanym progu wentylacyjnym (AT, anaerobic threshold) 10,42 ml/kg mc./ /min. Utrzymano dotychczasową terapię.

\section{Dyskusja}

Przedstawiono przypadek pacjenta z niewydolnością serca i obniżoną frakcją wyrzutową lewej komory (HFrEF, heart failure with reduced ejection fraction) leczonego zgodnie z aktualnymi wytycznymi najnowocześniejszą terapią, w tym antagonistą receptora AT1 dla angiotensyny II i inhibitora neprilizyny (ARNI, angiotensin receptor-nephrilysin inhibitor) oraz empagliflozyną. Według wytycznych empagliflozyna ma zalecenia klasy lla przy poziomie wiarygodności danych B i jest rekomendowana w celu zapobiegania HF lub opóźniania jej wystąpienia i przedłużania życia.

Inhibitory kotransportera sodu i glukozy typu 2 (SGLT2, sodium-glucose co-transporter 2) to jedne z najnowocześniejszych leków stosowanych w cukrzycy. Główny efekt ich działania wiąże się z wpływem na kanaliki nerkowe i zwiększeniem wydalania glukozy z moczem (glukozurią) poprzez zahamowanie jej zwrotnego transportu. Dzięki regulacji siły działania w zależności od stężenia glukozy we krwi ryzyko hipoglikemii w trakcie terapii pozostaje stosunkowo niskie, co umożliwia ich łączenie z praktycznie każda grupą leków przeciwcukrzycowych. Spodziewane obniżenie wartości $\mathrm{HbA}_{1 \mathrm{c}}$ w trakcie stosowania wyżej wspomnianej grupy leków wynosi 0,4-0,9 [7]. Ze względu na mechanizm transportu zwrotnego u tych chorych glukozurii towarzyszy natriureza. Wobec powyższego leki te charakteryzują się działaniem moczopędnym, które prowadzi do zmniejszenia objętości krwi krążącej, zmniejszenia masy ciała (m.in. wynikającej u chorych z HF z przewodnienia), obniżenia ciśnienia tętniczego i wzrostu hematokrytu [8]. Ponadto wyżej wymieniona grupa leków pozytywnie wpływa na inne parametry, takie jak otyłość brzuszna czy zmniejszenie stężenia kwasu moczowego czy mikroalbuminurii [9].

W coraz większej liczbie artykułów pojawiają się dowody korzystnego wpływu stosowania empagliflozyny na zmniejszenie ryzyka zdarzeń sercowo-naczyniowych ([MACE, major adverse cardiac event] określonych jako zgon z przyczyn sercowo-naczyniowych lub udar mózgu czy zawał serca niezakończony zgonem), jak również zmniejszenie liczby hospitalizacji z powodu zaostrzenia niewydolności krążenia - to efekt nieosiągany przy użyciu leków z innych grup stosowanych w farmakoterapii cukrzycy.

W trakcie badania EMPA-REG OUTCOME [10] wykazano 35-procentową redukcję ryzyka hospitalizacji z powodu zaostrzenia HF w grupie stosującej empagliflozynę. Ze względu na fakt, że badanie EMPA-REG OUTCOME nie było przeznaczone dla populacji z HF, zaprojektowano kolejne badania z udziałem tej populacji chorych, by ustalić miejsce empagliflozyny w terapii pacjentów z HF.

W badaniu CVD-REAL 2 [11] obejmującym ponad 300 tys. chorych na cukrzycę typu 2 z 6 krajów potwierdzono, że stosowanie leków z wyżej wymienionej grupy obniża ryzyko hospitalizacji z powodu zaostrzenia HF oraz śmiertelność. Według autorów badania możliwy jest efekt klasy, gdyż stosowanie innych inhibitorów SGLT2, a nie tylko empagliflozyny (stanowiącej < 10\% leków z tej grupy w powyższym badaniu) potwierdziło zmniejszenie liczby hospitalizacji z powodu HF oraz redukcję częstości innych niepożądanych zdarzeń sercowo-naczyniowych (tj. udaru mózgu, zawału serca) obserwowaną w badaniu EMPA-REG OUTCOME. W tabeli 2 przedstawiono najważniejsze, przeprowadzone dotychczas badania z zastosowaniem inhibitorów SGLT2 [10, 12, 13].

Mechanizmy wpływające na tak zaskakujące wyniki obniżenia ryzyka zdarzeń sercowo-naczyniowych przez inhibitory SGLT2 nie są do końca poznane. Wydaje się jednak oczywiste, że nie wynikają one jedynie z wpływu na SGLT2 i kontroli glikemii, między innymi ze względu na niską ekspresje genów dla SGLT2 na powierzchni kardiomiocytów, a także wczesny efekt działania wyżej wymienionych leków na istotne punkty końcowe oraz brak korelacji między glikemią czy wartością $\mathrm{HbA}_{1 \mathrm{c}} \mathrm{w}$ trakcie wizyt kontrolnych a redukcją liczby hospitalizacji z powodu HF.

Wśród istotnych czynników wymienia się wpływ tych substancji na hemostazę jonową w komórkach miokardium chorych na cukrzycę. Prawidłowe stężenie jonów wapnia $\left(\mathrm{Ca}^{2+}\right)$, a także szybkie zmiany ich wewnątrzkomórkowego stężenia odgrywają kluczową rolę w transmisji sygnału komórkowego, a więc odpowiadają za prawidłową regulację HR czy skurczu miokardiocytów. Na dynamikę zmian 
Tabela 2. Wybrane badania kliniczne dotyczące wpływu inhibitorów kotransporterów sodu i glukozy typu 2 (SGLT2, sodium-glucose co-transporter 2) na ryzyko sercowo-naczyniowe (na podstawie [10-13])

\begin{tabular}{|c|c|c|c|c|c|c|}
\hline \multirow[t]{2}{*}{ Parametr } & \multicolumn{6}{|c|}{ Nazwa badania } \\
\hline & $\begin{array}{c}\text { EMPA-REG } \\
\text { OUTCOME } \\
{[10,12]}\end{array}$ & $\begin{array}{c}\text { CVD-REAL } 2 \\
{[11,12]}\end{array}$ & $\begin{array}{l}\text { CVD-REAL } \\
\text { [12] }\end{array}$ & $\begin{array}{l}\text { EASEL } \\
\text { [12] }\end{array}$ & $\begin{array}{l}\text { CANVAS/ } \\
\text { /CANVAS-R } \\
{[12]}\end{array}$ & $\begin{array}{l}\text { DECLARE- } \\
\text {-TIMI } 58 \\
\text { [13] }\end{array}$ \\
\hline $\begin{array}{l}\text { Rodzaje stosowa- } \\
\text { nych inhibitorów } \\
\text { SGLT2 }\end{array}$ & Empagliflozyna & $\begin{array}{c}\text { Dapagliflozyna(75\%), } \\
\text { empagliflozyna (9\%), } \\
\text { ipragliflozyna (8\%), } \\
\text { kanagliflozyna (4\%), } \\
\text { tofogliflozyna (3\%), } \\
\text { luseogliflozyna (1\%) }\end{array}$ & $\begin{array}{c}\text { Kanagliflozyna } \\
\text { (53\%), } \\
\text { dapagliflozyna } \\
(42 \%), \\
\text { empagliflozyna } \\
(5 \%)\end{array}$ & $\begin{array}{c}\text { Kanagliflozyna } \\
(58 \%), \\
\text { empagliflozyna } \\
(26 \%), \\
\text { dapagliflozyna } \\
(16 \%)\end{array}$ & Kanagliflozyna & Dapagliflozyna \\
\hline $\begin{array}{l}\text { Liczba uczestni- } \\
\text { ków badania (n) }\end{array}$ & $>7000$ & $>400000$ & $>300000$ & $>25000$ & $>10000$ & $>17000$ \\
\hline Zawał serca & $0,87(0,70-1,09)$ & $0,81(0,74-0,88)$ & Brak danych & $0,81(0,64-1,03)$ & $0,89(0,73-1,09)$ & $0,89(0,77-1,01)$ \\
\hline Udar mózgu & $1,18(0,89-1,56)$ & $0,68(0,55-0,84)$ & Brak danych & $0,85(0,66-1,10)$ & $0,87(0,69-1,09)$ & $1,01(0,84-1,21)$ \\
\hline Śmiertelność & $0,68(0,57-0,82)$ & $0,51(0,37-0,70)$ & $0,49(0,41-0,57)$ & $0,57(0,49-0,66)$ & $0,87(0,74-1,01)$ & $0,93(0,82-1,04)$ \\
\hline $\begin{array}{l}\text { Hospitalizacja } \\
\text { z powodu niewy- } \\
\text { dolności serca }\end{array}$ & $0,65(0,50-0,85)$ & $0,64(0,50-0,82)$ & $0,61(0,51-0,73)$ & $0,57(0,45-0,73)$ & $0,67(0,52-0,87)$ & $0,73(0,61-0,88)$ \\
\hline
\end{tabular}

stężenia jonów wapnia wpływa stężenie jonów sodu regulowane między innymi przez pompę sodowo-potasową, pompę $\mathrm{Na}^{+} / \mathrm{H}^{+}$(NHE, $\mathrm{Na}^{+}-\mathrm{H}^{+}$exchange). Hemostaza - zarówno sodowa, jak i wapniowa - jest zachwiana w komórkach serca chorych na cukrzyce. W wyniku hipoksji, nasilenia wewnątrzkomórkowych procesów anaerobowych dochodzi do wytworzenia kwasu mlekowego, a w efekcie zmniejszenia pH wewnątrzkomórkowego i wyrównawczego uruchomienia pompy $\mathrm{Na}^{+} / \mathrm{H}^{+}$, co skutkuje przeładowaniem cytoplazmy jonami sodowymi [14].

Inhibitory SGLT2, poprzez zmniejszenie wewnątrzkomórkowego stężenia $\mathrm{Na}^{+}$, przesunięcie jonów wapnia do mitochondriów, a w konsekwencji poprawienie siły skurczu miocytów, prowadzą do poprawy funkcji skurczowej serca i zmniejszenia aktywacji układu współczulnego, co wydaje się szczególnie istotne w odniesieniu do serca chorego z obniżoną frakcją wyrzutową lewej komory, na przykład w przebiegu choroby wieńcowej, jak u opisanego pacjenta.

Według innej teorii stosowanie inhibitorów SGLT2 zmniejsza stres oksydacyjny (który odgrywa istotną rolę w utrzymaniu przewlekłej reakcji zapalnej w tkance mięśnia sercowego chorego na cukrzyce, a w konsekwencji prowadzi między innymi do apoptozy i włóknienia, przyczyniając się do niekorzystnego remodelingu serca), zmniejsza produkcję wolnych rodników i modyfikuje przemianę kwasów tłuszczowych w komórce, preferując jako substrat reakcji kwas betahydroksymasłowy, który jest najbardziej energetycznie korzystnym związkiem [14].

Warto także wspomnieć o bezpiecznym profilu empagliflozyny. Stosowana w monoterapii wiąże się z niskim ryzykiem hipoglikemii. Ze względu na główny efekt hipoglikemizujący, związany głównie z diurezą osmotyczną, wymaga względnie prawidłowej funkcji nerek, natomiast jednym z najczęstszych powikłań w związku z glukozurią są zakażenia układu moczowo-płciowego. Jednakże powikłane zakażenia dróg moczowych (np. odmiedniczkowe zapalenie nerek lub posocznica moczopochodna) występowały z podobną częstością u pacjentów otrzymujących empagliflozynę i placebo. W przedstawianym przypadku w trakcie terapii nie obserwowano infekcji dróg moczowych, rejestrowano natomiast zmniejszenie masy ciała i poprawę profilu glikemii, a sam lek był dobrze tolerowany przez chorego. Warto jeszcze wspomnieć o innym powikłaniu związanym prawdopodobnie z modyfikacją szlaku oksydacji tłuszczów, tj. kwasicą ketonową przy względnie prawidłowych glikemiach. Jednak w przeprowadzonych badaniach randomizowanych udowodniono, że ryzyko takiego powikłania jest bardzo niskie, zwłaszcza u chorych niewymagających insulinoterapii [12].

Mechanizmy prowadzące do nasilenia HF wynikają głównie z trzech przyczyn - zwiększenia obciążenia wstępnego (preload), obciążenia następczego (afterload) oraz zdolności „skurczowej” miokardiocytów. Według obecnego stanu wiedzy inhibitory SGLT2 działają wielokierunkowo. Poprzez diurezę osmotyczną i zmniejszenie ilości krwi krążącej zmniejszają preload. W wyniku obniżenia ciśnienia tętniczego oraz oporu naczyniowego zmniejszają afterload. Ponadto, wpływając na hemostazę jonów sodowych i wapniowych w komórkach, wpływają na siłę i „jakość” skurczu miokardiocytów.

W 2018 roku w Ameryce [12] ukazał się konsensus, w którym wysoko pozycjonowano inhibitory SGLT2 w algorytmie leczenia chorych z cukrzycą typu 2 i chorobą wieńcową. Już na poziomie edukacji dotyczącej zmiany stylu życia oraz włączenia metforminy zaleca się 


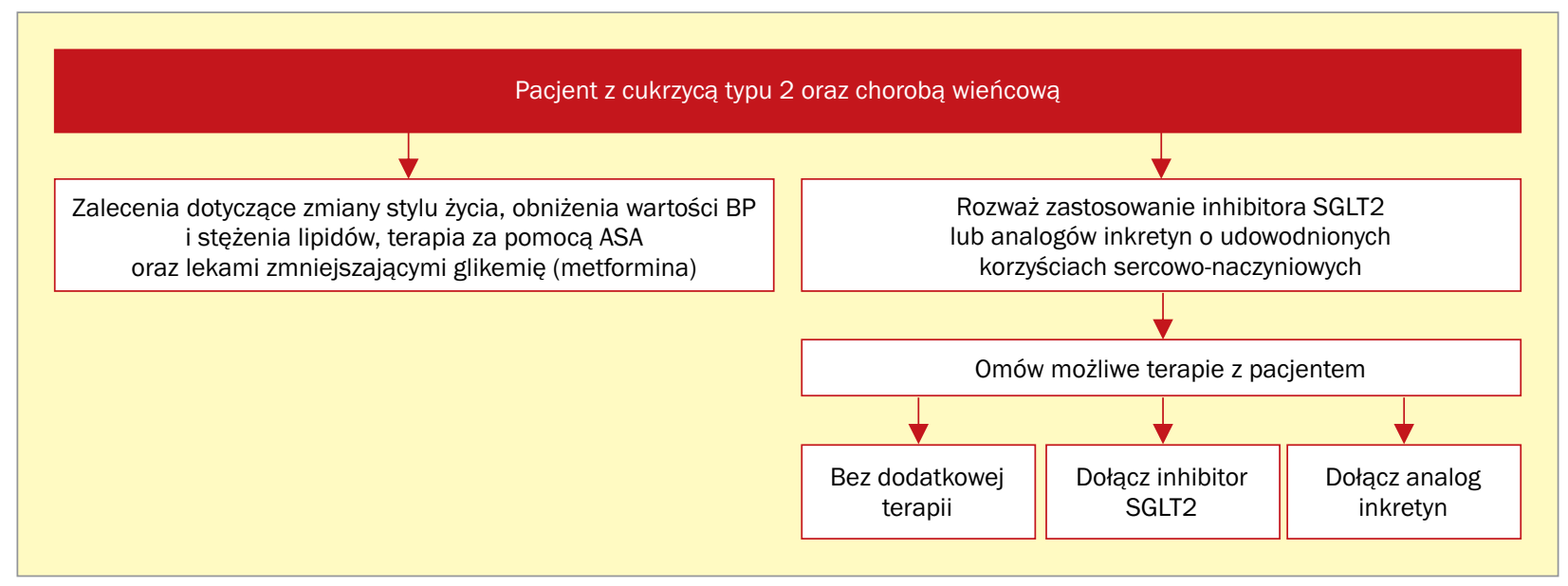

Rycina 1. Algorytm leczenia pacjenta z cukrzycą typu 2 oraz chorobą wieńcową (na podstawie [12]); BP (blood pressure) - ciśnienie tętnicze; ASA (acetylsalicylic acid) - kwas acetylosalicylowy; SGLT2 (sodium-glucose co-transporter 2) - kotransporter sodu i glukozy typu 2

rozważenie dołączenia między innymi inhibitora SGLT2 (patrz ryc. 1).

\section{Wnioski}

Empagliflozyna jest nowym narzędziem terapeutycznym dla pacjentów z HFrEF i wspótistniejącą cukrzyca. Przedstawiony przypadek kliniczny pacjenta obciążonego licznymi chorobami towarzyszącymi wskazuje na duży udział empagliflozyny w terapii HFrEF, o czym świadczy wystąpienie zaostrzenia niewydolności serca z koniecznością hospitalizacji po odstawieniu leku u pacjenta leczonego optymalną standardową terapią dla HFrEF z użyciem ARNI. Opisany przypadek pokazuje jak istotne może być wczesne wdrażanie nowoczesnej farmakoterapii i stosowanie zaleceń towarzystw eksperckich w codziennej praktyce klinicznej.

\section{Konflikt interesów}

Udział w badaniu klinicznym z zastosowaniem empagliflozyny.

\section{Abstract}

A 56 year-old man with severe dysfunction was admitted to the Department due to exacerbation of chronic heart failure with reduced left ventricular ejection fraction. During hospitalization the standard treatment of heart failure was used, but also there was a modification of pharmacotherapy in diabetes. Based on the clinical case description, the article shows the current state of knowledge on the beneficial effects of empagliflozin on the cardiovascular system.

Key words: heart failure with reduced ejection fraction, empagliflozin

Folia Cardiologica 2019; 14, 2: 199-205

\section{Piśmiennictwo}

1. Ponikowski P, Voors A, Anker S, et al. Wytyczne ESC dotyczące diagnostyki i leczenia ostrej i przewlekłej niewydolności serca w 2016 roku. Kardiol Pol. 2016; 74(10): 1037-1147, doi: 10.5603/kp.2016.0141.

2. McMurray JJV. Clinical practice. Systolic heart failure. N Engl J Med. 2010; 362(3): 228-238, doi: 10.1056/NEJMcp0909392, indexed in Pubmed: 20089973.

3. Dunlay SM, Redfield MM, Weston SA, et al. Hospitalizations after heart failure diagnosis a community perspective. J Am Coll Cardiol. 2009; 54(18): 1695-1702, doi: 10.1016/j.jacc.2009.08.019, indexed in Pubmed: 19850209.
4. Kannel WB, Hjortland M, Castelli WP. Role of diabetes in congestive heart failure: the Framingham study. Am J Cardiol. 1974; 34(1): 29-34, indexed in Pubmed: 4835750.

5. Metra M, Zacà V, Parati G, et al. Heart Failure Study Group of the Italian Society of Cardiology. Cardiovascular and noncardiovascular comorbidities in patients with chronic heart failure. J Cardiovasc Med (Hagerstown). 2011; 12(2): 76-84, doi: 10.2459/ /JCM.0b013e32834058d1, indexed in Pubmed: 20962666.

6. Jia G, Whaley-Connell A, Sowers JR. Diabetic cardiomyopathy: a hyperglycaemia- and insulin-resistance-induced heart disease. Diabetolo- 
gia. 2018; 61(1): 21-28, doi: 10.1007/s00125-017-4390-4, indexed in Pubmed: 28776083.

7. Scheen AJ. Pharmacokinetic and pharmacodynamic profile of empagliflozin, a sodium glucose co-transporter 2 inhibitor. Clin Pharmacokinet. 2014; 53(3): 213-225, doi: 10.1007/s40262-013-0126-x, indexed in Pubmed: 24430725.

8. Butler J, Hamo CE, Filippatos G, et al. EMPEROR Trials Program. The potential role and rationale for treatment of heart failure with sodium-glucose co-transporter 2 inhibitors. Eur J Heart Fail. 2017; 19(11): 1390-1400, doi: 10.1002/ejhf.933, indexed in Pubmed: 28836359.

9. Baptist $\mathrm{G}$. The cardiovascular benefits associated with the use of sodium-glucose cotransporter 2 inhibitors - real-world data. Eur Endocrinol. 2018; 14(1): 17-23, doi: 10.17925/EE.2018.14.1.17, indexed in Pubmed: 29922347.

10. Fitchett D, Zinman B, Wanner C, et al. EMPA-REG OUTCOME ${ }^{\oplus}$ Trial Investigators. Heart failure outcomes with empagliflozin in patients with type 2 diabetes at high cardiovascular risk: results of the EMPA-REG OUTCOME ${ }^{\circledast}$ trial. Eur Heart J. 2016; 37(19): 1526-1534, doi: 10.1093/eurheartj/ehv728, indexed in Pubmed: 26819227.
11. Kosiborod M, Lam CSP, Kohsaka S, et al. CVD-REAL Investigators and Study Group. Cardiovascular events associated with SGLT-2 lihibitors versus other glucose-lowering drugs: the CVD-REAL 2 study. J Am Coll Cardiol. 2018; 71(23): 2628-2639, doi: 10.1016/j. jacc.2018.03.009, indexed in Pubmed: 29540325.

12. Das SR, Everett BM, Birtcher KK, et al. 2018 ACC Expert Consensus decision pathway on novel therapies for cardiovascular risk reduction in patients with type 2 diabetes and atherosclerotic cardiovascular disease: a report of the American College of Cardiology Task Force on Expert Consensus Decision Pathways. J Am Coll Cardiol. 2018; 72(24): 3200-3223, doi: 10.1016/j.jacc.2018.09.020, indexed in Pubmed: 30497881.

13. Wiviott SD, Raz I, Bonaca MP, et al. DECLARE-TIMI 58 Investigators. Dapagliflozin and cardiovascular outcomes in type 2 diabetes. N Engl J Med. 2019; 380(4): 347-357, doi: 10.1056/NEJMoa1812389, indexed in Pubmed: 30415602.

14. Kaplan A, Abidi E, El-Yazbi A, et al. Direct cardiovascular impact of SGLT2 inhibitors: mechanisms and effects. Heart Fail Rev. 2018; 23(3): 419-437, doi: 10.1007/s10741-017-9665-9, indexed in Pubmed: 29322280. 